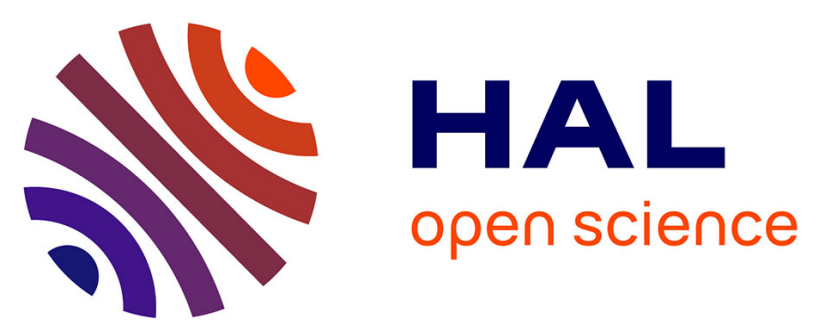

\title{
Population attributable fractions of mortality in people living with HIV: roles of delayed antiretroviral therapy, hepatitis coinfections and social factors
}

\author{
Melina Santos, Camelia Protopopescu, Rachel Ribeiro, Adele Benzaken, \\ Gerson Pereira, Antony Stevens, Marie Libérée Nishimwe, Issifou Yaya, \\ Patrizia M. Carrieri, Wildo Araújo
}

\section{To cite this version:}

Melina Santos, Camelia Protopopescu, Rachel Ribeiro, Adele Benzaken, Gerson Pereira, et al.. Population attributable fractions of mortality in people living with HIV: roles of delayed antiretroviral therapy, hepatitis coinfections and social factors. AIDS. Official journal of the international AIDS Society, 2020, 34 (12), pp.1843-1854. 10.1097/QAD.0000000000002621 . inserm-03104215

\section{HAL Id: inserm-03104215 https://www.hal.inserm.fr/inserm-03104215}

Submitted on 8 Jan 2021

HAL is a multi-disciplinary open access archive for the deposit and dissemination of scientific research documents, whether they are published or not. The documents may come from teaching and research institutions in France or abroad, or from public or private research centers.
L'archive ouverte pluridisciplinaire HAL, est destinée au dépôt et à la diffusion de documents scientifiques de niveau recherche, publiés ou non, émanant des établissements d'enseignement et de recherche français ou étrangers, des laboratoires publics ou privés. 
AIDS

Population attributable fractions of mortality in people living with HIV: roles of delayed ART, hepatitis coinfections and social factors

--Manuscript Draft--

Manuscript Number:

Full Title:

Article Type:

Keywords:

Corresponding Author:

Corresponding Author Secondary Information:

Corresponding Author's Institution:

Corresponding Author's Secondary Institution:

First Author:

First Author Secondary Information:

Order of Authors:

Order of Authors Secondary Information:
AIDS-D-19-01016R1

Population attributable fractions of mortality in people living with HIV: roles of delayed ART, hepatitis coinfections and social factors

Original paper (Epidemiology / Social)

HIV; Hepatitis C; Hepatitis B; Coinfection; Mortality; Socioeconomic Factors

Melina E. SANTOS, PhD

SESSTIM UMR 1252

Marseille, FRANCE

SESSTIM UMR 1252

Melina E. SANTOS, PhD

Melina E. SANTOS, PhD

Camelia PROTOPOPESCU, PhD

Rachel A RIBEIRO

Adele S BENZAKEN, PhD

Gerson F M PEREIRA, PhD

Antony STEVENS, PhD

Marie L NISHIMWE, MSc

Issifou YAYA, PhD

Patrizia CARRIERI, PhD

Wildo N ARAÜJO, PhD 
Despite free access to antiretroviral therapy (ART) from 1996 onward, and treatment for all people living with HIV (PLWHIV) from 2013, mortality in Brazil has not homogeneously decreased. We investigated to what extent delayed ART, hepatitis coinfections and sociodemographic factors predict all-cause mortality in Brazilian PLWHIV.

Design

We included PLWHIV 218 years, with complete CD4 count data, followed up between 2007 and 2015 in Brazil.

\section{Methods}

After multiple imputation, an extended Cox model helped estimate the effects of fixed and time-varying covariates on mortality.

\section{Results}

The study population ( $n=411,028)$ were mainly male $(61 \%)$, Caucasian $(55 \%)$, $s 40$ years (61\%), heterosexually HIV-infected $(71 \%)$, living in the Southeast region $(48 \%)$ and had basic education (79\%). HCV and HBV coinfection prevalences were $2.5 \%$ and $1.4 \%$, respectively. During a 4-year median follow-up, 61,630 deaths occurred and the mortality rate was 3.45 [95\% confidence interval (CI): 3.42-3.47] per 100 person-years. Older age, male gender, non-Caucasian ethnicity, illiteracy/basic education and living outside the Southeast and Central-West regions were independently associated with increased mortality. The main modifiable predictors of mortality were delayed ART (i.e., CD4<200 cells/mm3 at ART initiation) (adjusted population attributable fraction: 14.20\% [95\% Cl: 13.81-14.59]), being ART-untreated (14.06\% [13.54-14.59]), and ART-treated with unrecorded CD4 at ART initiation (5.74\% [5.26-6.21]). HCV and HBV coinfections accounted for $2.44 \%[2.26-2.62]$ and $0.42 \%$ [0.31-0.53] of mortality, respectively.

\section{Conclusions}

This study demonstrates that besides early ART and coinfection control, actions targeting males, non-Caucasians and illiterate people and those with basic education are important to reduce avoidable deaths among Brazilian PLWHIV. 


\title{
Title page
}

\section{Full title}

Population attributable fractions of mortality in people living with HIV: roles of delayed ART, hepatitis coinfections and social factors

\section{Short title}

\section{Attributable fractions of mortality in PLWHIV}

\author{
Authors \\ Melina E SANTOS ${ }^{1,2,3,4}$, Camelia PROTOPOPESCU ${ }^{3,4}$, Rachel A RIBEIRO ${ }^{5}$, Adele S \\ BENZAKEN $^{6}$, Gerson F M PEREIRA ${ }^{5}$, Antony STEVENS ${ }^{7}$, Marie L NISHIMWE ${ }^{3,4}$, \\ Issifou YAYA ${ }^{8}$, Patrizia CARRIERI ${ }^{3,4}$, Wildo N ARAÚJO ${ }^{9}$
}

\section{Affiliations}

1 Faculty of Health Sciences, University of Brasilia, Brasilia, Brazil

2 Faculty of Medical and Paramedical Sciences, Aix Marseille Univ, Marseille, France

3 INSERM, IRD, SESSTIM, Sciences Economiques \& Sociales de la Santé \& Traitement de l’Information Médicale, Aix Marseille Univ, Marseille, France

4 Observatoire régional de la santé Provence-Alpes-Côte d'Azur, ORS PACA, Marseille, France

5 Department of Chronic Diseases and Sexually Transmitted Infections, Ministry of Health of Brazil, Brasilia, Brazil

6 Aids Healthcare Foundation, Global Program, São Paulo, Brazil 
7 Department of Non-Communicable Diseases and Health Promotion, Ministry of Health of Brazil, Brasilia, Brazil

8 IRD, INSERM, Univ Montpellier, TransVIHMI, Montpellier, France

9 Faculty of Ceilandia, University of Brasilia, Brasilia, Brazil

\section{Corresponding author}

Melina E SANTOS

INSERM UMR1252 SESSTIM

Faculté de médecine - 27 Boulevard Jean Moulin

Marseille, 13005, France

$+33627119245$

melinabtu@gmail.com

\section{Total number of words}

3496 words

\section{Conflicts of Interest and Source of Funding}

The authors have nothing to disclose.

No funding was received for this work. 


\begin{abstract}
Objectives: Despite free access to antiretroviral therapy (ART) from 1996 onward, and treatment for all people living with HIV (PLWHIV) from 2013, mortality in Brazil has not homogeneously decreased. We investigated to what extent delayed ART, hepatitis coinfections and sociodemographic factors predict all-cause mortality in Brazilian PLWHIV.
\end{abstract}

Design: We included PLWHIV $\geq 18$ years, with complete CD4 count data, followed up between 2007 and 2015 in Brazil.

Methods: After multiple imputation, an extended Cox model helped estimate the effects of fixed and time-varying covariates on mortality.

Results: The study population $(\mathrm{n}=411,028)$ were mainly male $(61 \%)$, Caucasian $(55 \%)$, $\leq 40$ years $(61 \%)$, heterosexually HIV-infected (71\%), living in the Southeast region (48\%) and had basic education (79\%). HCV and HBV coinfection prevalences were $2.5 \%$ and $1.4 \%$, respectively. During a 4-year median follow-up, 61,630 deaths occurred and the mortality rate was 3.45 [95\% confidence interval (CI): $3.42-3.47]$ per 100 personyears. Older age, male gender, non-Caucasian ethnicity, illiteracy/basic education and living outside the Southeast and Central-West regions were independently associated with increased mortality. The main modifiable predictors of mortality were delayed ART (i.e., CD4 $<200$ cells $/ \mathrm{mm}^{3}$ at ART initiation) (adjusted population attributable fraction: $14.20 \%$ [95\% CI: 13.81-14.59]), being ART-untreated (14.06\% [13.54-14.59]), and ART-treated with unrecorded CD4 at ART initiation (5.74\% [5.26-6.21]). HCV and HBV coinfections accounted for $2.44 \%[2.26-2.62]$ and $0.42 \%[0.31-0.53]$ of mortality, respectively. 
Conclusions: This study demonstrates that besides early ART and coinfection control, actions targeting males, non-Caucasians and illiterate people and those with basic education are important to reduce avoidable deaths among Brazilian PLWHIV. 


\section{Keywords}

HIV; Hepatitis C; Hepatitis B; Coinfection; Mortality; Socioeconomic Factors. 


\section{Introduction}

HIV epidemic affects 37.9 million people worldwide, with 770,000 dying from HIVrelated causes in 2018 [1]. There are 966,058 people living with HIV (PLWHIV) in Brazil (2019 estimates), with an average of 40,000 new HIV infections annually [2]. The introduction of free antiretroviral therapy (ART) in 1996 under Brazil's Unified Health System (SUS) [3], and treatment for all PLWHIV in 2013 [4], led to a gradual decrease of HIV-related mortality between 2000 and 2014 [5]. The mortality profile of PLWHIV consequently changed, non-HIV-related causes of death becoming more prevalent (e.g., liver and cardiovascular diseases) $[6,7]$.

The main factors of mortality in PLWHIV are late presentation for HIV care [8,9], late diagnosis [8,9] and delayed ART [9,10], as well as discontinuity of care [11] and of treatment $[9,10]$. Coinfection with hepatitis C virus (HCV) [12-14] and hepatitis B virus (HBV) [12] is also associated with all-cause deaths among PLWHIV. Because of pathophysiologic synergy between the viruses, HCV coinfection accelerates progression to acquired immune deficiency syndrome (AIDS), and HIV infection stimulates liver disease progression $[15,16]$. Similarly, through a multifactorial interaction mechanism, HBV replication accelerates advanced fibrosis progression, increasing the risk of liver events and death [16].

Mortality among PLWHIV across Brazil has decreased, but not homogenously [5]. A national population-based study showed that CD4 $\leq 200$ cells $/ \mathrm{mm}^{3}$ at ART initiation was associated with HIV-related mortality [17]. Moreover, cohort studies in Brazil's Southeast region identified $\mathrm{HIV} / \mathrm{HCV}$ and $\mathrm{HIV} / \mathrm{HBV}$ coinfections as further predictors of HIV-related mortality [18]. 
In previous international studies, older age $[19,20]$, non-Caucasian ethnicity [21] and a low education level $[22,23]$ were all independently associated with increased mortality among PLWHIV. Likewise, a nationwide Brazilian study highlighted that a low education level and living outside the Southeast region were both associated with late presentation for care [24].

Given that early ART is currently the most effective strategy to control HIV-related morbidity and mortality [25], we presume that delayed ART might also be linked to allcause mortality in Brazilian PLWHIV. Accordingly, we suppose that coinfections and sociodemographic factors might also be associated with all-cause deaths in this population in Brazil.

The objective of our study was to investigate to what extent delayed ART, hepatitis coinfections and sociodemographic characteristics predict all-cause mortality in the country's HIV population. Using a national linkage database, representative of PLWHIV receiving care in Brazil, we identified the covariates associated with all-cause mortality among Brazilian PLWHIV and estimated the population attributable fraction (PAF) of the mortality rate due to each modifiable risk factor, while accounting for known predictors of mortality in this population.

\section{Methods}

\section{Databases}

Despite national coverage, the four country's databases (reflecting disease reporting, HIV laboratory tests, ART and death notification) [26-29], used in this study, do not have a common identification number. Accordingly, we performed a probabilistic record linkage using individual data (name, mother's maiden name, date of birth and city of birth) for 
the period January 1, 2007 to December 31, 2015, applying a Bloom filter [30]. We then checked for consistencies and duplicates, and removed all personal identification.

\section{Ethical considerations}

The ethics review board of the Faculty of Health Sciences at the University of Brasilia approved the study and provided a waiver of informed consent for secondary use of data. The Ministry of Health of Brazil agreed to data access exclusively for the study period.

\section{Study population}

The study population comprised all PLWHIV registered in SUS aged $\geq 18$ years old at the beginning of follow-up, with at least one recorded CD4 count between January 1, 2007 and December 31, 2015, and with complete data for gender, region of residence and hepatitis coinfections.

\section{Study design}

We performed a survival analysis with entry date (baseline) at the first available CD4 count date. The end of follow-up date was defined as the latest available news date (HIV laboratory test or death), with censoring at December 31, 2015 due to data availability.

\section{Outcome}

The outcome was all-cause deaths occurring between January 1, 2007 and December 31, 2015.

\section{Covariates}


Time-fixed covariates were age at baseline, gender, ethnicity, education level, HIV transmission mode, region of residence, and $\mathrm{HCV}$ and $\mathrm{HBV}$ coinfections. Education level was classified into three groups: illiteracy, basic education (defined here as primary/lower secondary education) and higher education (defined here as upper secondary/third-level education) [31].

HCV coinfection was defined as detectable anti-HCV antibodies and HCV-RNA, or International Classification of Diseases (ICD-10) codes B17.1/B18.2 as the cause of death. HBV coinfection was defined as detectable anti-HBV antibodies or hepatitis B virus surface antigen, or ICD-10 codes B16/B17.0/B18.0/B18.1 as the cause of death [32].

Time-varying covariates were CD4 count and ART status (treated versus untreated). All measures available for both covariates during the follow-up period were included. In addition, to test the effect of delayed ART, a combined time-varying variable was created using the interaction between ART status and the last available CD4 count (with 200 cells $/ \mathrm{mm}^{3}$ threshold) before ART initiation.

\section{Missing data}

Missing data concerned three of the covariates: ethnicity, education level and HIV transmission mode (we did not impute missing data concerning unrecorded CD4 counts before ART initiation, as this regarded individuals already on ART at baseline). Missing values for the three mentioned covariates were imputed before analysis using multiple imputation by chained equations (MICE) [33], under a missing at random assumption. All observed variables were used in the imputation process, generating 25 imputed sets. 


\section{Statistical analyses}

Global and regional mortality rates were computed as the number of all-cause deaths occurring during the study period divided by the number of person-years (PY) (i.e., the sum, for all patients, of the number of years between baseline and end of follow-up). An extended proportional hazard Cox model based on Breslow's estimates [34] was applied after multiple imputation. Hazard ratios (HR) and corresponding 95\% confidence intervals $(\mathrm{CI})$ were calculated by combining regression coefficients and standard errors from the model estimated for each of the imputed data sets. Since all covariates tested were very significantly associated with the outcome (Wald test p-value $<10^{-3}$ ) in univariable and multivariable analyses, the final multivariable model included all fixed covariates and the combined time-varying covariate.

The proportional risks assumption was tested graphically using scaled Schoenfeld residuals, log-log curves, and by comparing the Kaplan-Meier survival function with the model-predicted survival function [35].

Finally, for each of the modifiable factors, we estimated the PAF, defined as the proportion of mortality which could be avoided by risk factor modification [36,37]. We calculated adjusted PAF based on the final Cox multivariable model estimates across multiply imputed data sets using the punafcc Stata command for each category of interest. The punafcc command calculates the unattributable fraction, which is a mean betweenscenario HR (the real-world scenario of individuals at risk and not at risk, and a fantasy scenario where no one is at risk), which is then subtracted from 1 to provide the PAF $[38,39]$.

RStudio 2015 (RStudio, Inc., Boston, MA) and Stata/SE 14.2 (StataCorp LP, College Station, USA) were used for data treatment and for statistical analyses. 


\section{Subgroup and sensitivity analyses}

Subgroup analyses were performed for HIV/HCV-coinfected and non-HIV/HCVcoinfected individuals. Sensitivity analyses were performed for a region-by-region analysis, and by calendar period (pre- and post-2013, the year when treatment for all PLWHIV was implemented).

\section{Results}

\section{Descriptive analysis}

The study included 411,028 PLWHIV followed up in SUS between January 2007 and December 2015. There were 3,311,425 observations, with a mean of 8 records per person, and at least one record per person per year.

The study population were mainly aged between 18 and 39 years old (61.0\%) (median age: 36 years [interquartile range (IQR): $29-44$ years]), male (61.0\%), and residents in the Southeast region (48.2\%). Moreover, $2.5 \%$ and $1.4 \%$ were $\mathrm{HCV}$ - and HBV-coinfected, respectively. At baseline, $74.7 \%$ had a CD4 count $\geq 200$ cells $/ \mathrm{mm}^{3}$ and $78.6 \%$ were ARTuntreated. Among those with complete data, $54.7 \%$ were Caucasian, $79.3 \%$ had basic education, and $70.5 \%$ were heterosexually HIV-infected (Table 1).

Deceased individuals had a higher median age (40 years [IQR: 32-48 years]). Among those aged $\geq 50$ years, $22.8 \%$ died. Furthermore, $16.4 \%$ of men and approximately $15 \%$ of PLWHIV in each of Brazil's 5 regions also died. HCV and HBV coinfections accounted for $34.5 \%$ and $22.8 \%$, respectively, of those who died. At baseline, $24.7 \%$ of those treated with CD4 $<200$ cells $/ \mathrm{mm}^{3}$ at ART initiation died. From complete data, 
$14.3 \%$ of non-Caucasians, $20.7 \%$ of illiterate people and $35.1 \%$ of those HIV-infected through injecting drug use (IDU) died (Table 1).

\section{Survival analysis}

Among the 411,028 PLWHIV - accounting for 1,788,381 PY from 2007 to 2015 - there were 61,630 all-cause deaths. Median follow-up time was 4.24 years. Global mortality rate was 3.45 [95\% CI: 3.42-3.47] deaths per 100 PY. Mortality rate by region of residence varied from $3.26[3.22-3.29]$ to 4.45 [4.32-4.59] deaths per 100 PY in the Southeast and North regions, respectively (Figure 1).

\section{Univariable analyses}

All covariates were significantly associated with mortality in the univariable models (pvalue $<10^{-3}$ ) (Table 2$)$.

\section{Multivariable analysis}

In the multivariable analysis, the time-fixed covariates associated with an increased mortality were older age ('40-49 years' and ' $\geq 50$ years' (adjusted $\mathrm{HR}$ (aHR) $[95 \% \mathrm{CI}]$ : 1.22 [1.20-1.24] and 1.73 [1.69-1.77] versus '18-39 years', respectively), male gender (1.52 [1.49-1.55]), non-Caucasian ethnicity (1.15 [1.13-1.18] versus Caucasian), illiteracy and basic education (1.66 [1.57-1.75] and 1.27 [1.23-1.31] versus higher education, respectively). The HIV transmission modes associated with higher mortality were IDU (1.75 [1.65-1.85]) and heterosexual (1.26 [1.23-1.29]), versus transmission between men who have sex with men (MSM)/bisexual. Both HIV/HCV (1.73 [1.67- 
1.79]) and HIV/HBV (1.25 [1.18-1.32]) coinfections were independently associated with an increased mortality (Table 2).

With respect to region of residence, living in the North, Northeast and South regions was associated with higher mortality (1.27 [1.22-1.33], 1.13 [1.09-1.18] and 1.06 [1.02-1.10] versus living in the Central-West region, respectively). Furthermore, the time-varying factors associated with an increased mortality were being ART-untreated (1.78 [1.751.83]), ART-treated with CD4 $<200$ cells $/ \mathrm{mm}^{3}$ at ART initiation $(2.53$ [2.47-2.59]) and ART-treated with unrecorded CD4 at ART initiation (1.33 [1.30-1.36]) versus ARTtreated with CD4 $\geq 200$ cells $/ \mathrm{mm}^{3}$ at ART initiation (Table 2).

\section{Proportional hazards assumption}

The proportional hazards assumption was supported for all fixed covariates in the final multivariable model through graphical diagnosis (data not shown).

\section{Population attributable fractions (PAF)}

After adjusting for covariates in the multivariable model, PAF showed that 2.44\% [95\% CI: $2.26-2.62]$ and $0.42 \%$ [0.31-0.53] of the mortality rate was attributable to HCV and HBV coinfections, respectively. Moreover, delayed ART (CD4 $<200$ cells $/ \mathrm{mm}^{3}$ at ART initiation) accounted for $14.20 \%$ [13.81-14.59] of the mortality rate, ART-untreated for 14.06\% [13.54-14.59], and ART-treated with unrecorded CD4 at ART initiation for $5.74 \%[5.26-6.21]$ (Table 2).

\section{Subgroup analyses}


Among the 10,313 HIV/HCV-coinfected individuals (57,039 PY), 3,558 all-cause deaths occurred during the study period - i.e., a mortality rate of 6.24 [95\% CI: 6.04-6.45] deaths per $100 \mathrm{PY}$ - for a median follow-up time of 6.44 years.

HIV/HCV-coinfected individuals had a higher mortality than non-HIV/HCV-coinfected individuals for the following variables: older age ('40-49 years’ (aHR [95\% CI]: 1.38 [1.28-1.49] and ' $\geq 50$ years' (2.03 [1.85-2.22]) versus ' $18-39$ years'), and HIV/HCV/HBV triple coinfection (1.55 [1.36-1.76]). However, among HIV/HCV-coinfected individuals, living in the Southeast and South regions was associated with lower mortality $(0.68[0.56-$ $0.82]$ and 0.74 [0.62-0.90] versus living in the Central-West region, respectively) (Table $3)$.

As for modifiable factors in the HIV/HCV-coinfected subgroup, being ART-treated with CD4 $<200$ cells $/ \mathrm{mm}^{3}$ at ART initiation accounted for $7.92 \%$ [95\% CI: $\left.6.51-9.31\right]$ of the mortality rate, followed by being ART-untreated (7.12\% [5.20-9.01]) and ART-treated with unrecorded CD4 at ART initiation (3.52\% [0.87-6.10]). HIV/HCV/HBV triple coinfection accounted for $1.20 \%$ [1.13-1.27] of mortality (Table 3).

\section{Sensitivity analyses}

Sensitivity analyses revealed all the same predictors of mortality identified in the global analysis in all PLWHIV.

In the region-by-region analysis, mortality in older people was higher in the Central-West region ('40-49 years' (aHR [95\% CI]: 1.33 [1.23-1.44]) and ‘ $\geq 50$ years' (1.87 [1.712.05]) versus ' $18-39$ years') than elsewhere. Mortality was higher in the North region for HCV (2.53 [1.90-3.37]) and HBV (1.59 [1.27-1.99]) coinfections, as well as for ARTuntreated (2.58 [2.36-2.81]), ART-treated with CD4 $<200$ cells $/ \mathrm{mm}^{3}$ at ART initiation 
(3.50 [3.19-3.83]) and ART-treated with unrecorded CD4 at ART initiation (2.04 [1.792.32]) versus $A R T$-treated with $\mathrm{CD} 4 \geq 200$ cells $/ \mathrm{mm}^{3}$ at ART initiation. Being HIVinfected through IDU (1.96 [1.56-2.47]) (versus MSM/bisexual) was associated with higher mortality in the Northeast region. Finally, male gender (1.65 [1.59-1.72]), nonCaucasian ethnicity (1.27 [1.22-1.33]), illiteracy (2.26 [2.02-2.53]) and basic education $(1.39[1.30-1.48])$ (versus higher education) were associated with higher mortality in the South region (Table 4).

Analyses by calendar period showed that the mortality risk in ART-untreated individuals (versus ART-treated with CD4 $\geq 200$ cells $/ \mathrm{mm}^{3}$ at ART initiation) post-2013 (3.56 [3.413.71]) was twice as high as pre-2013 estimates (1.66 [1.62-1.71]) (data not shown).

\section{Discussion}

This is the largest study to date investigating all-cause mortality of PLWHIV followed up in Brazil's public health system between 2007 and 2015. Furthermore, it is the only study to estimate the proportion of deaths attributable to specific factors, which could be avoided by implementing targeted healthcare and health surveillance policies. The primary result is that delayed ART (i.e., CD4<200 cells $/ \mathrm{mm}^{3}$ at ART initiation) was the main modifiable predictor of mortality in PLWHIV in Brazil, accounting for approximately 1 in 6 deaths. As this result is independent of the other cofactors explored here, interventions ensuring early ART initiation for all PLWHIV - irrespective of CD4 counts - could decrease the mortality rate in Brazil's HIV population by $14 \%$.

Given that the mortality profile of PLWHIV has changed in the last few years [12], delayed ART was not only the leading predictor of all-cause deaths in PLWHIV in our study, but also among HIV/HCV-coinfected individuals, accounting for $8 \%$ of the 
mortality rate in this subgroup. Delayed ART has been associated elsewhere with an increased mortality in the HIV population due to HIV-related [10,40] and non-HIVrelated events $[41,42]$. Initiating ART with a CD4 $<200$ cells $/ \mathrm{mm}^{3}$ is also a proxy of late diagnosis and late presentation for care, which were both related to mortality in this population [43].

Despite insufficient data in our study for the period following the implementation of the government's 'treatment for all' policy, the mortality risk post-2013 in ART-untreated PLWHIV was twice that of pre-2013 level. As expected therefore, over the whole study period, being ART-untreated was a strong predictor of mortality.

Moreover, HCV and HBV coinfections were important modifiable factors of mortality in our study population, accounting for $2.44 \%$ and $0.42 \%$ of the mortality rate, respectively. These results are consistent with previous studies showing that HCV coinfection was associated with increased all-cause and HCV-related mortality in PLWHIV [18,19], as a consequence of cirrhosis, end-stage liver disease and hepatocellular carcinoma [44]. HBV coinfection was associated with lower CD4 count at ART initiation [45] and with higher mortality, despite early treatment in PLWHIV [46]. In our study, HIV/HCV/HBV triple coinfection accounted for $2.62 \%$ of the mortality rate, probably due to exacerbation of liver fibrosis [47].

Mortality in persons aged 50 years old and over was almost twice that in those aged between 18 and 39 years old. Previous studies showed that age-related comorbidities were more prevalent in PLWHIV because of chronic systemic inflammation and exposure to ART [48], resulting in excess mortality at older age [20]. Additionally, older HIV/HCVcoinfected individuals in our study faced higher mortality than non-HIV/HCV-coinfected 
people, probably because most of Brazil's HCV population are over 40 years old [49], and because liver disease takes longer to reach advanced stages [50].

In line with previous studies showing that men had higher HIV-related mortality than women [17,51,52], male gender was associated with an increased all-cause mortality in this study, especially among non-HIV/HCV-coinfected individuals. Our result suggests a remaining disproportionate risk of death for HIV-infected men, as reported before [52]. This could be explained by the relationship encountered between male gender and late presentation for care [53], HIV late diagnosis [54], and delayed ART [52].

With respect to HIV transmission mode, mortality in people infected through IDU was almost twice as high as in those infected through MSM/bisexual intercourse. Nevertheless, the proportion of HIV infection through IDU in our study diminished from $2.5 \%$ in 2007 to $0.4 \%$ in 2015 , confirming a tendency towards a decreasing impact of this predictor of mortality [17], historically associated with IDU until the 1990s in Brazil [55]. The effect of IDU transmission mode in our population reflects previous findings where IDU-based HIV infection was associated with a higher risk of late diagnosis and higher HIV-related mortality than sexual transmission [56].

Indeed, heterosexual HIV transmission was associated with higher mortality in our population than MSM/bisexual transmission. Elsewhere, heterosexual HIV transmission was independently associated with late presentation for care and late presentation with advanced disease [53]. Given that MSM in general are at higher risk of acquiring HIV due to their sexual behaviors [57], and that HIV is more prevalent among them [58], they are tested more often. Accordingly, they are usually diagnosed early and have better linkage to care [59]. The fact that heterosexual transmission has been the primary reported 
mode of HIV infection in Brazil since 2000 [2] underlines the need for HIV testing in heterosexual couples.

We also found that non-Caucasian ethnicity - previously linked to HIV-related mortality in Brazil $[60,61]$ - was associated with higher all-cause mortality. In other international studies, non-Caucasians had higher all-cause mortality [62,63], lower life expectancy [64] and higher levels of HIV care discontinuity [21] than PLWHIV of Caucasian ethnicity. The lack of any association between non-Caucasian ethnicity and mortality in the $\mathrm{HIV} / \mathrm{HCV}$-coinfected subgroup in our study may be due to the lower prevalence of recorded non-Caucasian ethnicity among Brazilian HIV/HCV-coinfected individuals [65].

Furthermore, we found that illiteracy and basic education were strong predictors of mortality, which strengthens previous evidence showing that low education level is associated with higher mortality among PLWHIV [18,23]. Education level has been associated with healthy behaviors, improved self-assessed health, greater life expectancy, lower morbidity and lower mortality from different causes [66]. In addition, it may reflect socioeconomic status, which was related to increased HIV-related mortality in other cohorts [67] and considered a determinant of survival in PLWHIV [68].

With regard to region of residence, we revealed geographical and social inequalities in terms of PLWHIV mortality in Brazil. The North region was associated with higher mortality, probably because the extension of the HIV epidemic through rural Amazon areas continues to complicate access to care [69]. Besides, as HBV is endemic in this region [70,71], $\mathrm{HIV} / \mathrm{HCV}$ coinfection and $\mathrm{HIV} / \mathrm{HCV} / \mathrm{HBV}$ triple coinfection may be diagnosed late and therefore have a greater impact, as revealed in the region-by-region analysis. 
The Northeast region was also associated with higher mortality in our study. A previous study found a greater proportion of non-HIV-related causes of death than HIV-related causes among deceased PLWHIV in this region [72], possibly reflecting more accurate reporting of deaths there. Our region-by-region analysis showed that PLWHIV infected through IDU faced higher mortality in the Northeast than elsewhere. This is surprising, as historically HIV incidence among people who use drugs has been higher in the Southeast and South regions $[73,74]$. The fact that risk reduction policies are better implemented in the Southeast region [75], and the possibility that these policies are not yet sufficiently extended to the country's other regions, may explain this.

Living in the South region was associated with higher mortality in the global analysis, presumably because of the stronger impact of certain sociodemographic factors (male gender, non-Caucasian ethnicity and illiteracy/basic education), highlighted in the regionby-region analysis. This is consistent with previous research revealing that the HIV epidemic is generalized throughout most of this region [76,77]. Indeed, the HIV mortality rate there has been higher than national estimates since 2008 [2].

By contrast, living in the Southeast and South regions was associated with lower mortality among HIV/HCV-coinfected people. This might be explained by better health infrastructure [78], as well as sociodemographic and environmental conditions [24] in these regions, which may translate into improved early diagnosis and greater linkage to care [79].

The major strength of our study is its representativeness of the entire HIV population in Brazil, including people that present late for care and for treatment. Our results provide valuable information to minimize sociodemographic inequalities and therefore improve survival in the Brazilian PLWHIV population. 
Other study strengths and limitations concern the use of secondary data. While information systems may be subject to underreporting and data misclassification [80], secondary databases may be an efficient strategy to represent a real-world cohort and diminish the risk of bias related to time-varying factors [81]. In order to reduce the underascertainment of coinfection prevalence based on disease notification [82], we also included deaths related to $\mathrm{HCV}$ and to $\mathrm{HBV}$ in the case definition of hepatitis coinfections. With regard to incomplete data, multiple imputation estimates allowed us to minimize selection bias [33]. As we accounted for all-cause deaths, underestimation of mortality in our study is unlikely.

In conclusion, besides modifiable factors (i.e., delayed ART and hepatitis coinfections), sociodemographic characteristics were significant predictors of all-cause mortality in PLWHIV in Brazil. This highlights the importance of actions targeting specific populations (males, non-Caucasians, illiterate people and those with basic education), which goes beyond early ART and coinfections control, in order to reduce avoidable deaths among Brazilian PLWHIV. 


\section{Acknowledgments}

Melina E SANTOS performed the research, analyzed the data and wrote the paper. Camelia PROTOPOPESCU and Patrizia CARRIERI designed the study and guided the research. Rachel A RIBEIRO and Antony STEVENS performed the record linkage. Gerson F M PEREIRA contributed to the data access, as did Adele S BENZAKEN who also provided ideas for drafting the paper. Marie L NISHIMWE and Issifou YAYA contributed to the data management. Wildo N ARAÚJO contributed to the study's conception and design. All authors approved the final version. Fábio MESQUITA, MD, $\mathrm{PhD}$, and team leader of HIV and Viral Hepatitis at the WHO Country Office in Myanmar, contributed to the study and gave valuable input to the paper. Finally, our thanks to Jude SWEENEY for the English revision and editing of this manuscript. 


\section{References}

1 World Health Organization. HIV/AIDS. 2019.https://www.who.int/newsroom/fact-sheets/detail/hiv-aids (accessed 13 Apr2020).

2 Ministério da Saúde. Secretaria de Vigilância em Saúde. Boletim Epidemiológico Especial. HIV/Aids 2019. ; 2019. http://www.aids.gov.br/ptbr/pub/2019/boletim-epidemiologico-de-hivaids-2019 (accessed 13 Apr2020).

3 Laurindo-Teodorescu L, Teixeira PR. Histórias da Aids no Brasil: as respostas governamentais à epidemia de Aids. ; 2015.

4 Benzaken AS, Pereira GFM, Costa L, Tanuri A, Santos AF, Soares MA. Antiretroviral treatment, government policy and economy of HIV/AIDS in Brazil: is it time for HIV cure in the country? AIDS Res Ther 2019; 16:19.

5 Guimarães MDC, Carneiro M, De Abreu DMX, França EB. HIV/AIDS Mortality in Brazil, 2000-2015: Are there reasons for concern? Rev Bras Epidemiol 2017; 20:182-190.

6 Paula AA, Schechter M, Tuboi SH, Faulhaber JC, Luz PM, Veloso VG, et al. Continuous increase of cardiovascular diseases, diabetes, and non-HIV related cancers as causes of death in $\mathrm{HIV}$-infected individuals in Brazil: An analysis of nationwide data. PLoS One 2014; 9:e94636.

7 Grinsztejn B, Luz PM, Pacheco AG, Santos DVG, Velasque L, Moreira RI, et al. Changing mortality profile among HIV-infected patients in Rio de Janeiro, Brazil: shifting from AIDS to non-AIDS related conditions in the HAART era. PLoS One 2013; 8:e59768.

8 May MT, Vehreschild JJ, Trickey A, Obel N, Reiss P, Bonnet F, et al. Mortality According to CD4 Count at Start of Combination Antiretroviral Therapy 
among HIV-infected Patients Followed for up to 15 Years after Start of Treatment: Collaborative Cohort Study. Clin Infect Dis 2016; 62:1571-1577. Belaunzarán-Zamudio PF, Caro-Vega YN, Shepherd BE, Rebeiro PF, CrabtreeRamírez BE, Cortes CP, et al. The Population Impact of Late Presentation with Advanced HIV Disease and Delayed Antiretroviral Therapy in Adults Receiving HIV Care in Latin America. Am J Epidemiol 2019; :kwz252.

10 The Opportunistic Infections Project Team of the Collaboration of Observational HIV Epidemiological Research in Europe (COHERE) in EuroCoord. CD4 cell count and the risk of AIDS or death in HIV-infected adults on combination antiretroviral therapy with a suppressed viral load: A longitudinal cohort study from COHERE. PLoS Med 2012; 9:e1001194.

11 Jose S, Delpech V, Howarth A, Burns F, Hill T, Porter K, et al. A continuum of HIV care describing mortality and loss to follow-up: a longitudinal cohort study. Lancet HIV 2018; 5:e301-e308.

12 Thornton AC, Jose S, Bhagani S, Chadwick D, Dunn D, Gilson R, et al. Hepatitis B, hepatitis C, and mortality among HIV-positive individuals. AIDS 2017; 31:2525-2532.

13 Grebely J, Raffa JD, Lai C, Kerr T, Fischer B, Krajden M, et al. Impact of hepatitis $\mathrm{C}$ virus infection on all-cause and liver-related mortality in a large community-based cohort of inner city residents. J Viral Hepat 2011; 18:3241.

14 Berenguer J, Alejos B, Hernando V, Viciana P, Salavert M, Santos I, et al. Trends in mortality according to hepatitis $\mathrm{C}$ virus serostatus in the era of combination antiretroviral therapy. AIDS 2012; 26:2241-2246. 
15 Rallón N, García M, García-Samaniego J, Rodríguez N, Cabello A, Restrepo C, et al. HCV coinfection contributes to HIV pathogenesis by increasing immune exhaustion in CD8 T-cells. PLoS One 2017; 12:e173943.

16 Singh KP, Crane M, Audsley J, Avihingsanon A, Sasadeusz J, Lewin SR. HIVhepatitis B virus coinfection: epidemiology, pathogenesis, and treatment. AIDS 2017; 31:2035-2052.

17 Mangal TD, Meireles MV, Pascom ARP, De Almeida Coelho R, Benzaken AS, Hallett TB. Determinants of survival of people living with HIV/AIDS on antiretroviral therapy in Brazil 2006-2015. BMC Infect Dis 2019; 19:206.

18 Alencar WK, Duarte PS, Waldman EA. Survival analysis of acquired immune deficiency syndrome patients with and without hepatitis $\mathrm{C}$ virus infection at a reference center for sexually transmitted diseases/acquired immune deficiency syndrome in Sao Paulo, Brazil. Brazilian J Infect Dis 2014; 18:150157.

19 Alejos B, Hernando V, Iribarren J, Gonzalez-Garcia J, Hernando A, Santos J, et al. Overall and cause-specific excess mortality in HIV-positive persons compared with the general population: Role of $\mathrm{HCV}$ coinfection. Medicine (Baltimore) 2016; 95:e4727.

20 Hentzien M, Dramé M, Delpierre C, Allavena C, Cabié A, Cuzin L, et al. HIVrelated excess mortality and age-related comorbidities in patients with HIV aged $\geq 60$ : a relative survival analysis in the French Dat'AIDS cohort. $B M J$ Open 2019; 9:e024841.

21 Rebeiro PF, Abraham AG, Horberg MA, Althoff KN, Yehia BR, Buchacz K, et al. Sex, Race, and HIV Risk Disparities in Discontinuity of HIV Care After 
Antiretroviral Therapy Initiation in the United States and Canada. AIDS Patient Care STDS 2017; 31:129-144.

22 Del AJ, Lodi S, Dray-Spira R, Wittkop L, Monge S, Braun D, et al. Inequalities by educational level in response to combination antiretroviral treatment and survival in HIV-positive men and women in Europe. AIDS 2017; 31:253-262.

23 GBD 2017 Disease and Injury Incidence and Prevalence Collaborators, James SL, Abate D, Abate KH, Abay SM, Abbafati C, et al. Global, regional, and national incidence, prevalence, and years lived with disability for 354 diseases and injuries for 195 countries and territories, 1990-2017: a systematic analysis for the Global Burden of Disease Study 2017. Lancet (London, England) 2018; 392:1789-1858.

24 Pascom ARP, Meireles MV, Benzaken AS. Sociodemographic determinants of attrition in the HIV continuum of care in Brazil, in 2016. Medicine (Baltimore) 2018; 97:S69-S74.

25 Sáez-Cirión A, Bacchus C, Hocqueloux L, Avettand-Fenoel V, Girault I, Lecuroux C, et al. Post-Treatment HIV-1 Controllers with a Long-Term Virological Remission after the Interruption of Early Initiated Antiretroviral Therapy ANRS VISCONTI Study. PLOS Pathog 2013; 9:1-12.

26 Ministério da Saúde. SINAN. Sistema de informação de agravos de notificação. 2019.http://portalsinan.saude.gov.br/sinan (accessed 13 Apr2020).

27 De Almeida WDS, Szwarcwald CL, De Frias PG, De Souza Júnior PRB, De Lima RB, De Lyra Rabello Neto D, et al. Capturing deaths not informed to the Ministry of Health: proactive search of deaths in Brazilian municipalities. Rev Bras Epidemiol 2017; 20:200-211. 
28 Ministério da Saúde. Secretaria de Vigilância em Saúde. Departamento de Doenças de Condições Crônicas e Infecções Sexualmente Transmissíveis. Sistema de Controle de Exames Laboratoriais da Rede Nacional de Contagem de Linfócitos CD4+/CD8+ e Carga Viral do HIV (SISCEL). 2019.http://www.aids.gov.br/pt-br/sistema-de-informacao/sistema-de-controlede-exames-laboratoriais-da-rede-nacional-de-contagem-de (accessed 13 Apr2020).

29 Ministério da Saúde. Secretaria de Vigilância em Saúde. Departamento de Doenças de Condições Crônicas e Infecções Sexualmente Transmissíveis. Sistema de Controle Logístico de Medicamentos (SICLOM). 2019.http://www.aids.gov.br/pt-br/gestores/sistemas-de-informacao/sistema-decontrole-logistico-de-medicamentos-siclom (accessed 13 Apr2020).

30 Schnell R, Bachteler T, Reiher J. Privacy-preserving record linkage using Bloom filters. BMC Med Inform Decis Mak 2009; 9:41.

31 OCDE. Education Policy Outlook: Brazil. OECD Publishing; 2015. www.oecd.org/education/policyoutlook.htm (accessed 13 Apr2020).

32 World Health Organization. International Statistical Classification of Diseases and Related Health Problems. 10th Revision. Volume 2 Instruction manual. WHO Press; 2010.

33 Li P, Stuart EA, Allison DB. Multiple Imputation: A Flexible Tool for Handling Missing Data. JAMA 2015; 314:1966-1967.

34 Jullum M, Hjort NL. What price semiparametric Cox regression? Lifetime Data Anal 2019; 25:406-438.

35 Zhang Z, Reinikainen J, Adeleke KA, Pieterse ME, Groothuis-Oudshoorn CGM. 
Time-varying covariates and coefficients in Cox regression models. Ann Transl Med 2018; 6:121.

36 Brooks-Pollock E, Danon L. Defining the population attributable fraction for infectious diseases. Int J Epidemiol 2017; 46:976-982.

37 Mansournia MA, Altman DG. Population attributable fraction. BMJ 2018; 360:k757.

38 von Cube M, Schumacher M, Bailly S, Timsit J-F, Lepape A, Savey A, et al. The population-attributable fraction for time-dependent exposures and competing risks-A discussion on estimands. Stat Med 2019; 38:3880-3895.

39 Newson RB. Attributable and unattributable risks and fractions and other scenario comparisons. Stata J 2013; 13:672-698.

40 Collaboration Antiretroviral Therapy Cohort, Trickey A, May MT, Vehreschild J-J, Obel N, Gill MJ, et al. Survival of HIV-positive patients starting antiretroviral therapy between 1996 and 2013: a collaborative analysis of cohort studies. Lancet HIV 2017; 4:e349-e356.

41 Smith C, Sabin C a, Lundgren JD, Thiebaut R, Weber R, Law M, et al. Factors associated with specific causes of death amongst HIV-positive individuals in the D:A:D Study. AIDS 2010; 24:1537-48.

42 Klein MB, Althoff KN, Jing Y, Lau B, Kitahata M, Lo Re V, et al. Risk of EndStage Liver Disease in HIV-Viral Hepatitis Coinfected Persons in North America from the Early to Modern Antiretroviral Therapy Eras. Clin Infect Dis 2016; 63:1160-1167.

43 Croxford S, Kitching A, Desai S, Kall M, Edelstein M, Skingsley A, et al. Mortality and causes of death in people diagnosed with HIV in the era of 
highly active antiretroviral therapy compared with the general population: an analysis of a national observational cohort. Lancet Public Heal 2017; 2:e35-e46.

44 Ingiliz P, Rockstroh JK. Natural history of liver disease and effect of hepatitis C virus on HIV disease progression. Curr Opin HIV AIDS 2015; 10:303-308.

45 Thio CL, Smeaton L, Saulynas M, Hwang H, Saravan S, Kulkarni S, et al. Characterization of $\mathrm{HIV}-\mathrm{HBV}$ coinfection in a multinational HIV-infected cohort. AIDS 2013; 27:191-201.

46 Kouamé G-M, Boyd A, Moh R, Badje A, Gabillard D, Ouattara E, et al. Higher Mortality Despite Early Antiretroviral Therapy in Human Immunodeficiency Virus and Hepatitis B Virus (HBV)-Coinfected Patients With High HBV Replication. Clin Infect Dis 2017; 66:112-120.

47 Sterling RK, Wahed AS, King WC, Kleiner DE, Khalili M, Sulkowski M, et al. Spectrum of Liver Disease in Hepatitis B Virus (HBV) Patients Co-infected with Human Immunodeficiency Virus (HIV): Results of the HBV-HIV Cohort Study. Am J Gastroenterol 2019; 114:746-757.

Guaraldi G, Orlando G, Zona S, Menozzi M, Carli F, Garlassi E, et al. Premature Age-Related Comorbidities Among HIV-Infected Persons Compared With the General Population. Clin Infect Dis 2011; 53:1120-1126. 49 Amaku M, Burattini MN, Coutinho FAB, Lopez LF, Mesquita F, Naveira MCM, et al. Estimating the Size of the HCV Infection Prevalence: A Modeling Approach Using the Incidence of Cases Reported to an Official Notification System. Bull Math Biol 2016; 78:970-990. 
Incidence and progression to cirrhosis of new hepatitis $\mathrm{C}$ virus infections in persons living with human immunodeficiency virus. Clin Microbiol Infect 2017; 23:267.e1-267.e4.

51 Coelho L, Grinsztejn B, Castilho JL, Boni R, Quintana MSB, Campos DP, et al. Mortality in HIV-infected women, heterosexual men, and men who have sex with men in Rio de Janeiro, Brazil: an observational cohort study. Lancet HIV 2016; 3:e490-98.

52 Dovel K, Yeatman S, Watkins S, Poulin M. Men's heightened risk of AIDSrelated death: the legacy of gendered HIV testing and treatment strategies. AIDS 2015; 29:1123-1125.

53 Darcis G, Lambert I, Sauvage AS, Frippiat F, Meuris C, Uurlings F, et al. Factors associated with late presentation for HIV care in a single Belgian reference center: 2006-2017. Sci Rep 2018; 8:8594.

54 Tang H, Mao Y, Tang W, Han J, Xu J, Li J. "Late for testing, early for antiretroviral therapy, less likely to die": Results from a large HIV cohort study in China, 2006-2014. BMC Infect Dis 2018; 18:1-13.

55 Malta M, Magnanini MMF, Mello MB, Pascom ARP, Linhares Y, Bastos FI. HIV prevalence among female sex workers, drug users and men who have sex with men in Brazil: A Systematic Review and Meta-analysis. BMC Public Health 2010; 10:317.

56 Suarez-Garcia I, Sobrino-Vegas P, Dalmau D, Rubio R, Iribarren JA, Blanco JR, et al. Clinical outcomes of patients infected with HIV through use of injected drugs compared to patients infected through sexual transmission: late presentation, delayed anti-retroviral treatment and higher mortality. 
Addiction 2016; 111:1235-1245.

57 Champenois K, Seng R, Persoz A, Essat A, Gaud C, Laureillard D, et al. Calendar trends in sexual behaviours in a cohort of HIV-infected MSM at the era of treatment as prevention of HIV infection. AIDS 2018; 32:18711879.

58 Solomon SS, Mehta SH, Srikrishnan AK, Vasudevan CK, Mcfall AM, Balakrishnan $\mathrm{P}$, et al. High HIV prevalence and incidence among men who have sex with men (MSM) across 12 cities in India. AIDS 2015; 29:723-731.

59 Hoots BE, Finlayson TJ, Wejnert C, Paz-Bailey G, Group NS. Early Linkage to HIV Care and Antiretroviral Treatment among Men Who Have Sex with Men--20 Cities, United States, 2008 and 2011. PLoS One 2015; 10:e132962e0132962.

60 Lima T de A, Beyrer C, Golub JE, Mota JC da, Malta MS, Silva CMFP da, et al. Inequalities in HAART uptake and differential survival according to exposure category in Rio de Janeiro, Brazil. Cad Saude Publica 2018; 34:e00009617.

61 Melo MC de, Mesquita FC, Barros MB de A, La-Rotta EIG, Donalisio MR. Survival of patients with AIDS and association with level of education level and race/skin color in South and Southeast Brazil: a cohort study, 19981999. Epidemiol Serv Saude 2019; 28:e2018047.

62 Sheehan DM, Trepka MJ, Fennie KP, Prado G, Cano MÁ, Maddox LM. BlackWhite Latino Racial Disparities in HIV Survival, Florida, 2000-2011. Int J Environ Res Public Health 2016; 13:9.

63 Siddiqi A-A, Hu X, Hall HI. Mortality Among Blacks or African Americans 
with HIV Infection - United States, 2008-2012. Morb Mortal Wkly Rep 2015; 64:81-115.

64 Siddiqi A-E-A, Hall HI, Hu X, Song R. Population-Based Estimates of Life Expectancy After HIV Diagnosis: United States 2008-2011. J Acquir Immune Defic Syndr 2016; 72:230-236.

65 Oliveira SB de, Merchán-Hamann E, Amorim LDAF. HIV/AIDS coinfection with the hepatitis B and C viruses in Brazil. Cad Saude Publica 2014; 30:4338.

66 Hahn RA, Truman BI. Education Improves Public Health and Promotes Health Equity. Int J Heal Serv 2015; 45:657-678.

67 Kabudula CW, Houle B, Collinson MA, Kahn K, Gómez-Olivé FX, Tollman S, et al. Socioeconomic differences in mortality in the antiretroviral therapy era in Agincourt, rural South Africa, 2001-13: a population surveillance analysis. Lancet Glob Heal 2017; 5:e924-e935.

68 Abgrall S, Del Amo J. Effect of sociodemographic factors on survival of people living with HIV. Curr Opin HIV AIDS 2016; 11:501-506.

69 Oliveira R do SM de, Benzaken AS, Saraceni V, Sabidó M. HIV/AIDS epidemic in the State of Amazonas: characteristics and trends from 2001 to 2012. Rev Soc Bras Med Trop 2015; 48:70-78.

70 Vivaldini SM, Pinto FKA, Kohiyama IM, Almeida EC de, Mendes-Correa MC, Santos AF, et al. Exploratory spatial analysis of HBV cases in Brazil between 2005 and 2017. Rev Bras Epidemiol 2019; 22:e190007.

71 Ximenes RAA, Figueiredo GM, Cardoso MRA, Stein AT, Moreira RC, Coral G, et al. Population-based multicentric survey of hepatitis $B$ infection and risk 
factors in the North, South, and Southeast Regions of Brazil, 10-20 years after the beginning of vaccination. Am J Trop Med Hyg 2015; 93:1341-1348.

Filho D de B, Melo HRL de, et al. Use of the Coding Causes of Death in HIV in the classification of deaths in Northeastern Brazil. Rev Saude Publica 2017; 51:88.

73 Hacker MA, Leite IC, Renton A, Torres TG de, Gracie R, Bastos FI.

Reconstructing the AIDS epidemic among injection drug users in Brazil. Cad Saude Publica 2006; 22:751-760.

74 Bastos F, Pina M, Szwarcwald C. The social geography of HIV/AIDS among injection drug users in Brazil. Int J Drug Policy 2002; 13:137-144.

75 Mesquita F, Bueno R, Araujo PJ, Piconez D, Turienzo L G, Haddad IMT. Rapidly responding to injecting drug use and HIV in Brazil: a field-report from São Vicente, São Paulo State. Int J Drug Policy 2000; 11:133-144.

76 Pereira GFM, Shimizu HE, Bermudez XP, Hamann EM. Epidemiology of HIV and AIDS in the state of Rio Grande do Sul, Brazil, 1980-2015. Epidemiol Serv Saude 2018; 27:e2017374.

77 Amorim LT, Schlemper Junior BR. HIV/AIDS in small cities in Midwest Santa Catarina, south of Brazil: Clinical and epidemiological aspects, opportunistic infections. Rev Soc Bras Med Trop 2019; 52:e20180430.

78 Nemes MIB, Melchior R, Basso CR, Castanheira ERL, Alves MTSS de B, Conway S. The variability and predictors of quality of AIDS care services in Brazil. BMC Health Serv Res 2009, 9:51--51. BMC Health Serv Res 2009; 9:51. 
79 Santos MA, Guimarães MDC, Helena ETS, Basso CR, Vale FC, Carvalho WM do ES, et al. Monitoring self-reported adherence to antiretroviral therapy in public HIV care facilities in Brazil: A national cross-sectional study. Medicine (Baltimore) 2018; 97:S38-S45.

80 Gibbons CL, Mangen M-JJ, Plass D, Havelaar AH, Brooke RJ, Kramarz P, et al. Measuring underreporting and under-ascertainment in infectious disease datasets: a comparison of methods. BMC Public Health 2014; 14:147.

81 Schneeweiss S. Learning from big health care data. N Engl J Med 2014; 370:2161-2163.

82 Amaku M, Burattini MN, Chaib E, Coutinho FAB, Greenhalgh D, Lopez LF, et al. Estimating the prevalence of infectious diseases from under-reported agedependent compulsorily notification databases. Theor Biol Med Model 2017; 14:23. 


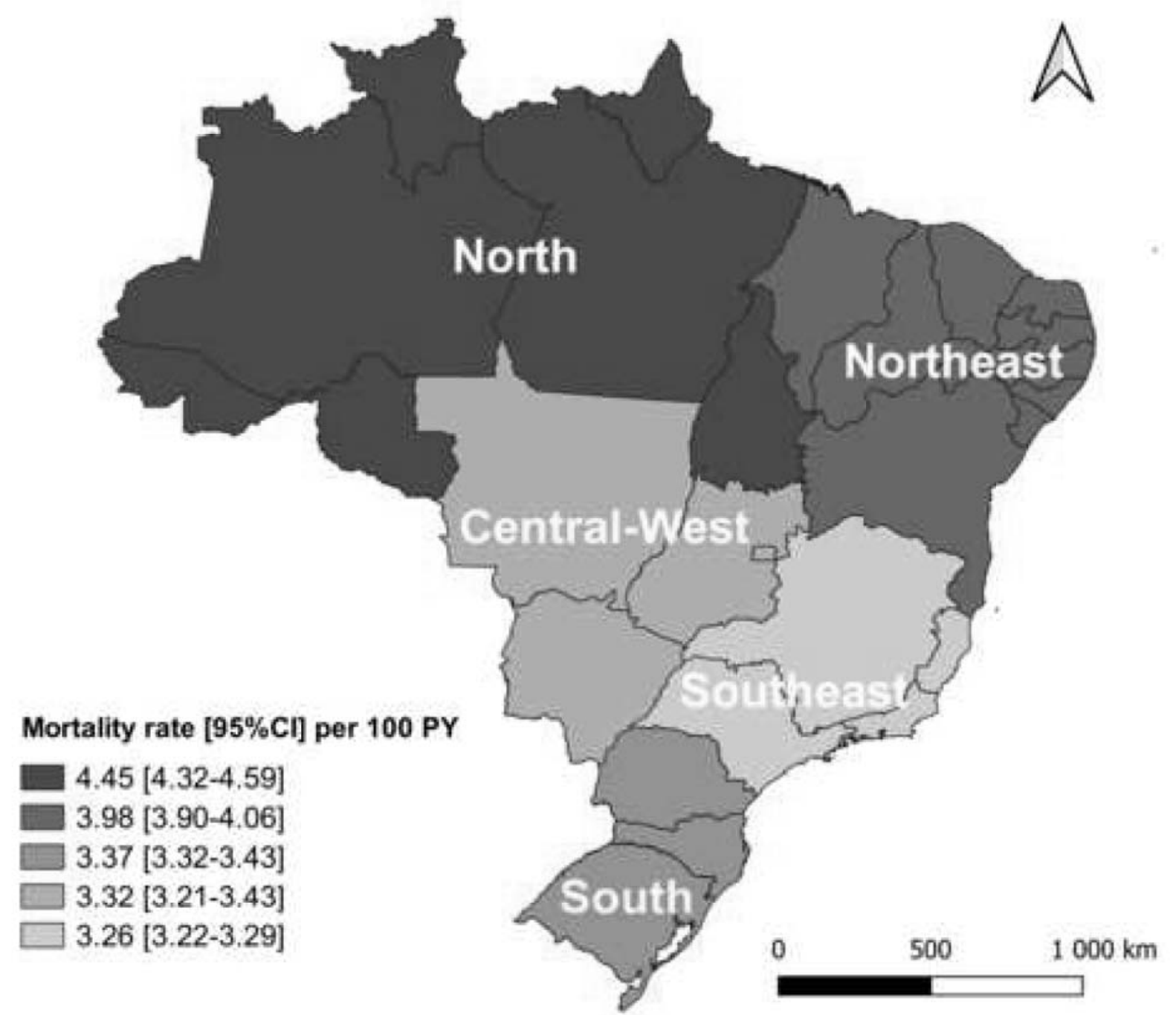

Figure 1. Mortality rate by region of residence per 100 person-years (PY) in the study population (Brazil, 2007-2015, $\mathrm{N}=411,028$ ) 
Table 1. Characteristics of individuals and all-cause deaths in the study population, and according to HIV/HCV coinfection (Brazil, 2007$2015, \mathrm{~N}=411,028)$

\begin{tabular}{|c|c|c|c|c|c|c|}
\hline \multirow[b]{3}{*}{ Covariates } & \multicolumn{2}{|c|}{ Study population } & \multicolumn{2}{|c|}{ HIV/HCV coinfected } & \multicolumn{2}{|c|}{ Not $\mathrm{HIV} / \mathrm{HCV}$ coinfected } \\
\hline & \multicolumn{2}{|c|}{$\mathbf{N}(\%)^{*}$} & \multicolumn{2}{|c|}{$\mathbf{N}(\%)^{*}$} & \multicolumn{2}{|c|}{$\mathbf{N}(\%)^{*}$} \\
\hline & Total & All-cause & Total & All-cause & Total & All-cause \\
\hline & individuals & deaths & individuals & deaths & individuals & deaths \\
\hline & $(\mathrm{N}=411,028)$ & $(n=61,630)^{* *}$ & $(\mathrm{~N}=10,313)$ & $(n=3,558) * *$ & $(N=400,715)$ & $(\mathrm{n}=\mathbf{5 8 , 0 7 2})^{* *}$ \\
\hline \multicolumn{7}{|l|}{ Age (years) } \\
\hline Median [IQR] & $36[29-44]$ & $40[32-48]$ & $41[36-47]$ & $43[37-48]$ & 36 [29-44] & $39[32-48]$ \\
\hline $18-39$ & $250,816(61.0)$ & $30,361(12.1)$ & $4,420(42.9)$ & $1,250(28.3)$ & $246,396(61.5)$ & $29,111(11.8)$ \\
\hline $40-49$ & $102,393(24.9)$ & $18,100(17.7)$ & $4,213(40.8)$ & $1,550(36.8)$ & $98,180(24.5)$ & $16,550(16.9)$ \\
\hline$\geq 50$ & $57,819(14.1)$ & $13,169(22.8)$ & $1,680(16.3)$ & $758(45.1)$ & $56,139(14.0)$ & $12,411(22.1)$ \\
\hline \multicolumn{7}{|l|}{ Gender $^{\S}$} \\
\hline Female & $160,346(39.0)$ & $20,509(12.8)$ & $2,865(27.8)$ & $858(30.0)$ & $157,481(39.3)$ & $19,651(12.5)$ \\
\hline Male & $250,682(61.0)$ & $41,121(16.4)$ & $7,448(72.2)$ & $2,700(36.3)$ & $243,234(60.7)$ & $38,421(15.8)$ \\
\hline
\end{tabular}




\begin{tabular}{|c|c|c|c|c|c|c|}
\hline \multirow[b]{3}{*}{ Covariates } & \multicolumn{2}{|c|}{ Study population } & \multicolumn{2}{|c|}{ HIV/HCV coinfected } & \multicolumn{2}{|c|}{ Not HIV/HCV coinfected } \\
\hline & \multicolumn{2}{|c|}{$\mathbf{N}(\%)^{*}$} & \multicolumn{2}{|c|}{$\mathbf{N}(\%)^{*}$} & \multicolumn{2}{|c|}{$\mathbf{N}(\%)^{*}$} \\
\hline & Total & All-cause & Total & All-cause & Total & All-cause \\
\hline & individuals & deaths & individuals & deaths & individuals & deaths \\
\hline & $(\mathrm{N}=411,028)$ & $(n=61,630)^{* *}$ & $(\mathrm{~N}=10,313)$ & $(n=3,558)^{* *}$ & $(\mathrm{~N}=400,715)$ & $(\mathbf{n}=\mathbf{5 8 , 0 7 2})^{* *}$ \\
\hline \multicolumn{7}{|l|}{ Ethnicity ${ }^{\S}$} \\
\hline Caucasian & $152,379(54.7)$ & $19,337(12.7)$ & $4,978(65.4)$ & $1,544(31.0)$ & $147,401(54.4)$ & $17,793(12.1)$ \\
\hline Non-Caucasian & $126,174(45.3)$ & $18,091(14.3)$ & $2,632(34.6)$ & $820(31.2)$ & $123,542(45.6)$ & $17,271(14.0)$ \\
\hline Missing*** & $132,475(32.2)$ & $24,202(39.3)$ & $2,703(26.2)$ & $1,194(33.6)$ & $129,772(32.4)$ & $23,008(39.6)$ \\
\hline \multicolumn{7}{|l|}{ Education level $^{\S}$} \\
\hline Higher education & $39,298(17.5)$ & $2,747(7.0)$ & $782(12.4)$ & $175(22.4)$ & $38,516(17.6)$ & $2,572(6.7)$ \\
\hline Basic education & $177,955(79.3)$ & $24,033(13.5)$ & $5,358(85.3)$ & $1,639(30.6)$ & $172,597(79.1)$ & $22,394(13.0)$ \\
\hline Illiteracy & $7,266(3.2)$ & $1,505(20.7)$ & $144(2.3)$ & $65(45.1)$ & $7,122(3.3)$ & $1,440(20.2)$ \\
\hline Missing*** & $186,509(45.4)$ & $33,345(54.1)$ & $4,029(39.1)$ & $1,679(47.2)$ & $182,480(45.5)$ & $31,666(54.5)$ \\
\hline
\end{tabular}

\section{HIV transmission mode ${ }^{\S}$}




\begin{tabular}{|c|c|c|c|c|c|c|}
\hline \multirow[b]{3}{*}{ Covariates } & \multicolumn{2}{|c|}{ Study population } & \multicolumn{2}{|c|}{ HIV/HCV coinfected } & \multicolumn{2}{|c|}{ Not HIV/HCV coinfected } \\
\hline & \multicolumn{2}{|c|}{$\mathbf{N}(\%) *$} & \multicolumn{2}{|c|}{$\mathbf{N}(\%) *$} & \multicolumn{2}{|c|}{$\mathbf{N}(\%) *$} \\
\hline & Total & All-cause & Total & All-cause & Total & All-cause \\
\hline & individuals & deaths & individuals & deaths & individuals & deaths \\
\hline & $(\mathrm{N}=411,028)$ & $(n=61,630)^{* *}$ & $(\mathrm{~N}=10,313)$ & $(n=3,558)^{* *}$ & $(\mathrm{~N}=400,715)$ & $(\mathbf{n}=58,072)^{* *}$ \\
\hline MSM/bisexual & $67,144(28.0)$ & $7,951(11.8)$ & $1,408(18.4)$ & $431(30.6)$ & $65,736(28.3)$ & $7,520(11.4)$ \\
\hline Heterosexual & $168,960(70.5)$ & $29,000(17.2)$ & $5,402(70.4)$ & $1,788(33.1)$ & $163,558(70.5)$ & $27,212(16.6)$ \\
\hline IDU & $3,729(1.5)$ & $1,307(35.1)$ & $860(11.2)$ & $339(39.4)$ & $2,869(1.2)$ & $968(33.7)$ \\
\hline Missing $* * *$ & $171,195(41.7)$ & 23,372 (37.9) & $2,643(25.6)$ & $1,000(28.1)$ & $168,552(42.1)$ & $22,372(38.5)$ \\
\hline \multicolumn{7}{|c|}{ Region of residence $^{\S}$} \\
\hline Central-West & $26,259(6.4)$ & $3,654(13.9)$ & $310(3.0)$ & $130(41.9)$ & $25,949(6.5)$ & $3,524(13.6)$ \\
\hline Southeast & $198,332(48.2)$ & $30,352(15.3)$ & $6,262(60.7)$ & $2,151(34.4)$ & $192,070(47.9)$ & $28,201(14.7)$ \\
\hline North & $29,017(7.1)$ & $4,301(14.8)$ & $91(0.9)$ & $50(55.0)$ & $28,926(7.2)$ & $4,251(14.7)$ \\
\hline Northeast & $61,684(15.0)$ & $9,293(15.1)$ & $248(2.4)$ & $98(39.5)$ & $61,436(15.3)$ & $9,195(15.0)$ \\
\hline South & $95,736(23.3)$ & $14,030(14.7)$ & $3,402(33.0)$ & $1,129(33.2)$ & $92,334(23.1)$ & $12,901(14.0)$ \\
\hline
\end{tabular}




\begin{tabular}{|c|c|c|c|c|c|c|}
\hline \multirow{5}{*}{ Covariates } & \multicolumn{2}{|c|}{ Study population } & \multicolumn{2}{|c|}{ HIV/HCV coinfected } & \multicolumn{2}{|c|}{ Not HIV/HCV coinfected } \\
\hline & \multicolumn{2}{|c|}{$\mathbf{N}(\%)^{*}$} & \multicolumn{2}{|c|}{$\mathbf{N}(\%) *$} & \multicolumn{2}{|c|}{$\mathbf{N}(\%) *$} \\
\hline & Total & All-cause & Total & All-cause & Total & All-cause \\
\hline & individuals & deaths & individuals & deaths & individuals & deaths \\
\hline & $(\mathrm{N}=411,028)$ & $(n=61,630)^{* *}$ & $(\mathrm{~N}=10,313)$ & $(n=3,558) * *$ & $(\mathrm{~N}=400,715)$ & $(\mathbf{n}=\mathbf{5 8 , 0 7 2})^{* *}$ \\
\hline \multicolumn{7}{|l|}{ HCV coinfection ${ }^{\S \S}$} \\
\hline Not $\mathrm{HCV}$ coinfected & $400,715(97.5)$ & $58,072(14.5)$ & \multirow[b]{2}{*}{ NA } & \multirow[b]{2}{*}{ NA } & \multirow[b]{2}{*}{ NA } & \multirow[b]{2}{*}{ NA } \\
\hline HCV coinfected & $10,313(2.5)$ & $3,558(34.5)$ & & & & \\
\hline \multicolumn{7}{|l|}{ HBV coinfection ${ }^{\S}$} \\
\hline Not HBV coinfected & $405,331(98.6)$ & $60,330(14.9)$ & $9,793(95.0)$ & $3,296(33.7)$ & $395,538(98.7)$ & $57,034(14.4)$ \\
\hline HBV coinfected & $5,697(1.4)$ & $1,300(22.8)$ & $520(5.0)$ & $262(50.4)$ & $5,177(1.3)$ & $1,038(20.1)$ \\
\hline \multicolumn{7}{|l|}{ CD4 count $\left(\text { cells } / \mathbf{m m}^{3}\right)^{\S \S \S}$} \\
\hline CD4 $\geq 200$ & $307,191(74.7)$ & $31,327(10.2)$ & $7,826(75.9)$ & $2,360(30.2)$ & $299,365(74.7)$ & $28,967(9.7)$ \\
\hline CD4 $<200$ & $103,837(25.3)$ & $30,303(29.2)$ & $2,487(24.1)$ & $1,198(48.2)$ & $101,350(25.3)$ & $29,105(28.7)$ \\
\hline ART status $s^{\S \S}$ & & & & & & \\
\hline
\end{tabular}




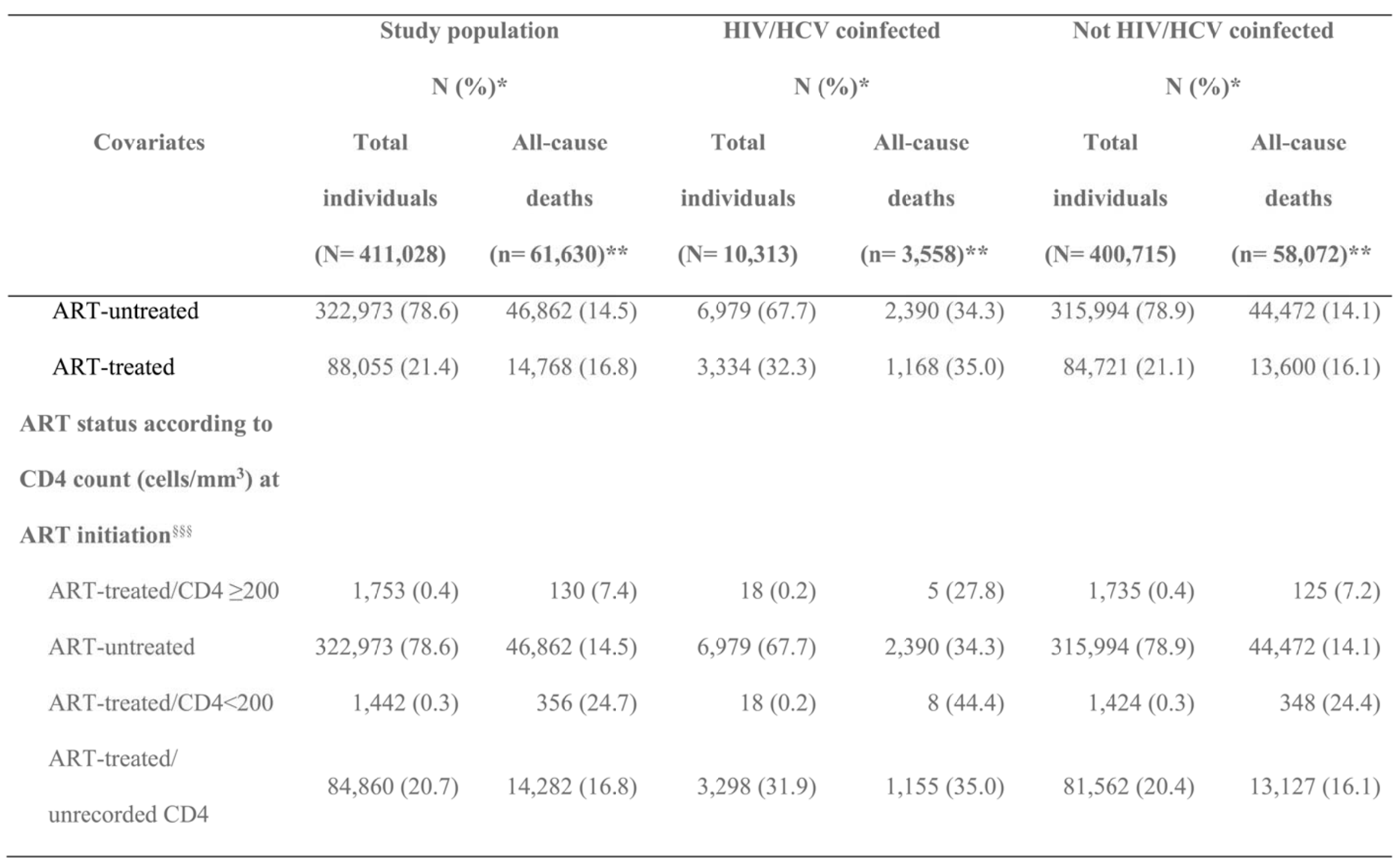


ART, antiretroviral therapy; HBV, hepatitis B virus; $\mathrm{HCV}$, hepatitis $\mathrm{C}$ virus; IDU, injecting drug use; IQR, interquartile range; MSM, men who have sex with men; NA, not applicable.

* The distribution of explanatory covariates does not include missing values.

** The proportion of all-cause deaths is calculated according to covariate category.

*** The proportion of missing values is shown among total individuals and all-cause deaths.

${ }^{\S}$ Fixed covariate, measured at baseline.

${ }^{\S}$ Fixed covariate, measured at baseline or at death (i.e., death notification).

$\$ \S$ Time-varying covariate, descriptive statistics given for baseline. 
Table 2. Factors associated with all-cause mortality in the study population (univariable and multivariable analyses, extended Cox model with multiple-imputation, Brazil, 2007-2015, N=411,028)

All-cause deaths $(n=61,630)$

Covariates

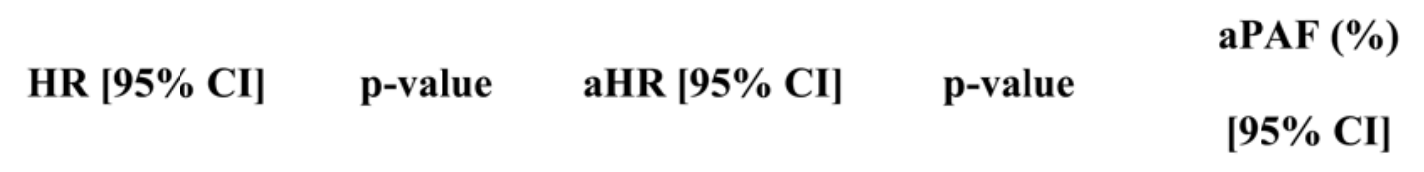

\begin{tabular}{|c|c|c|c|c|c|}
\hline \multicolumn{6}{|l|}{ Age (years) } \\
\hline $18-39$ (ref) & 1 & & 1 & & \multirow{3}{*}{ NA } \\
\hline $40-49$ & $1.27[1.24-1.29]$ & $<10^{-3}$ & $1.22[1.20-1.24]$ & $<10^{-3}$ & \\
\hline$\geq 50$ & $1.76[1.73-1.80]$ & $<10^{-3}$ & $1.73[1.69-1.76]$ & $<10^{-3}$ & \\
\hline \multicolumn{6}{|l|}{ Gender $^{\S}$} \\
\hline Female (ref) & 1 & & 1 & & \multirow[b]{2}{*}{ NA } \\
\hline Male & $1.44[1.42-1.46]$ & $<10^{-3}$ & $1.52[1.49-1.55]$ & $<10^{-3}$ & \\
\hline \multicolumn{6}{|l|}{ Ethnicity $^{\S}$} \\
\hline Caucasian (ref) & 1 & & 1 & & \multirow[b]{2}{*}{ NA } \\
\hline Non-Caucasian & $1.19[1.17-1.21]$ & $<10^{-3}$ & $1.15[1.13-1.18]$ & $<10^{-3}$ & \\
\hline
\end{tabular}




\section{All-cause deaths $(n=61,630)$}

Covariates

HR $[95 \%$ CI $] \quad$ p-value aHR $[95 \%$ CI $] \quad$ p-value

aPAF (\%)

$[95 \% \mathrm{CI}]$

\section{Education level $^{\S}$}

Higher education (ref)

Basic education

Illiteracy

1.37 [1.33-1.41]

$<10^{-3}$

$1.27[1.23-1.31]$

$<10^{-3}$

NA

IV transmission mode ${ }^{\S}$

MSM/bisexual (ref)

1

$<10^{-3}$

$1.66[1.57-1.75]$

$<10^{-3}$

Heterosexual

$\begin{array}{llll}1.17[1.15-1.20] & <10^{-3} & 1.26[1.23-1.29] & <10^{-3} \\ 2.00[1.90-2.12] & <10^{-3} & 1.75[1.65-1.85] & <10^{-3}\end{array}$

IDU

Region of residence 


\begin{tabular}{|c|c|c|c|c|c|}
\hline \multirow[b]{2}{*}{ Covariates } & \multicolumn{5}{|c|}{ All-cause deaths $(n=61,630)$} \\
\hline & HR $[95 \% \mathrm{CI}]$ & p-value & aHR $[95 \% \mathrm{CI}]$ & p-value & $\begin{array}{l}\text { aPAF (\%) } \\
{[95 \% \mathrm{CI}]}\end{array}$ \\
\hline Central-West (ref) & 1 & & 1 & & \\
\hline Southeast & $0.99[0.96-1.03]$ & 0.608 & $1.01[0.97-1.04]$ & 0.658 & \\
\hline North & $1.30[1.24-1.36]$ & $<10^{-3}$ & $1.27[1.22-1.33]$ & $<10^{-3}$ & NA \\
\hline Northeast & 1.18 [1.14-1.23] & $<10^{-3}$ & $1.13[1.09-1.18]$ & $<10^{-3}$ & \\
\hline South & $1.02[0.98-1.06]$ & 0.335 & $1.06[1.02-1.10]$ & 0.002 & \\
\hline \multicolumn{6}{|l|}{ HCV coinfection ${ }^{\S \S}$} \\
\hline Not HCV coinfected (ref) & 1 & & 1 & & \\
\hline HCV coinfected & $1.91[1.85-1.97]$ & $<10^{-3}$ & $1.73[1.67-1.79]$ & $<10^{-3}$ & $2.44[2.26-2.62]$ \\
\hline \multicolumn{6}{|l|}{ HBV coinfection ${ }^{\S}$} \\
\hline Not HBV coinfected (ref) & 1 & & 1 & & \\
\hline HBV coinfected & $1.38[1.30-1.45]$ & $<10^{-3}$ & $1.25[1.18-1.32]$ & $<10^{-3}$ & $0.42[0.31-0.53]$ \\
\hline
\end{tabular}




\section{All-cause deaths $(n=61,630)$}

Covariates

HR $[95 \% \mathrm{CI}] \quad$ p-value $\quad$ aHR $[95 \% \mathrm{CI}] \quad$ p-value

aPAF (\%)

$[95 \% \mathrm{CI}]$

\section{ART status according to CD4 count}

$\left(\right.$ cells $\left./ \mathrm{mm}^{3}\right)$ at $\mathrm{ART}$ initiation ${ }^{\S \S}$

ART-treated / CD4 $\geq 200$ (ref)

1

ART-untreated

$1.78[1.75-1.83]$

$<10^{-3}$

$14.06[13.54-14.59]$

ART-treated / CD4 <200

$2.70[2.63-2.76]$

$<10^{-3}$

$2.53[2.47-2.59]$

$<10^{-3}$

$14.20[13.81-14.59]$

ART-treated / unrecorded CD4

$1.38[1.35-1.41]$

$<10^{-3} \quad 1.33[1.30-1.36$

$<10^{-3}$

$5.74[5.26-6.21]$

aHR, adjusted hazard ratio; aPAF, adjusted population attributable fraction; ART, antiretroviral therapy; CI, confidence interval; HBV, hepatitis B virus; $\mathrm{HCV}$, hepatitis $\mathrm{C}$ virus; $\mathrm{HR}$, hazard ratio; IDU, injecting drug use; MSM, men who have sex with men; NA, not applicable.

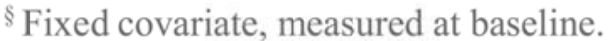

${ }^{\S}$ Fixed covariate, measured at baseline or at death (i.e., death notification).

$\S \S \S$ Time-varying covariate. 
Table 3. Factors associated with all-cause mortality according to HIV/HCV coinfection (multivariable analysis, extended Cox model with multiple imputation, Brazil, 2007-2015, N=411,028)

\section{All-cause deaths $(n=61,630)$}

\begin{tabular}{|c|c|c|c|c|c|c|}
\hline \multirow[t]{2}{*}{ Covariates } & \multicolumn{3}{|c|}{$(\mathrm{n}=\mathbf{3 , 5 5 8})$} & \multicolumn{3}{|c|}{$(\mathrm{n}=\mathbf{5 8 , 0 7 2})$} \\
\hline & aHR [95\% CI] & p-value & aPAF (\%) $[95 \%$ CI $]$ & aHR $[95 \%$ CI] & p-value & aPAF (\%) $[95 \%$ CI $]$ \\
\hline \multicolumn{7}{|l|}{ Age $($ years) } \\
\hline $18-39$ (ref) & \multicolumn{2}{|l|}{1} & \multicolumn{4}{|c|}{1} \\
\hline $40-49$ & $1.38[1.28-1.49]$ & $<10^{-3}$ & \multirow[t]{2}{*}{ NA } & $1.21[1.19-1.24]$ & $<10^{-3}$ & \multirow[t]{2}{*}{ NA } \\
\hline$\geq 50$ & $2.03[1.85-2.22]$ & $<10^{-3}$ & & $1.71[1.68-1.75]$ & $<10^{-3}$ & \\
\hline \multicolumn{7}{|l|}{ Gender $^{\S}$} \\
\hline Female (ref) & 1 & & \multirow[b]{2}{*}{ NA } & 1 & & \multirow[b]{2}{*}{ NA } \\
\hline Male & $1.25[1.15-1.35]$ & $<10^{-3}$ & & 1.54 [1.51-1.57] & $<10^{-3}$ & \\
\hline Ethnicity ${ }^{\S}$ & & & & & & \\
\hline
\end{tabular}


All-cause deaths $(n=61,630)$

Covariates

HIV/HCV coinfected

$(\mathrm{n}=\mathbf{3 , 5 5 8})$
Not HIV/HCV coinfected

$(n=58,072)$

aHR [95\% CI] p-value aPAF (\%) [95\% CI] aHR [95\% CI] p-value aPAF (\%) $[95 \%$ CI]

$\begin{array}{lrrrrr}\text { Caucasian (ref) } & 1 & & & 1 & \\ & & \text { NA } & 1.16[1.13-1.18] & <10^{-3} & \text { NA }\end{array}$

\section{Education level $^{\S}$}

Higher education (ref)

1

Basic education

$1.14[1.00-1.31]$

0.049

NA

1

Illiteracy

$1.60[1.22-2.09] \quad 0.001$

$1.27[1.23-1.32] \quad<10^{-3}$

NA

$1.66[1.57-1.76] \quad<10^{-3}$

\section{HIV transmission mode ${ }^{\S}$}

MSM/bisexual (ref)

Heterosexual

1.08 [0.97-1.20]

0.160

IDU

1.20 [1.05-1.38]

0.009

$$
\begin{array}{ll}
1.27[1.24-1.30] & <10^{-3} \\
1.95[1.83-2.09] & <10^{-3}
\end{array}
$$

\section{Region of residence}


All-cause deaths $(n=61,630)$

Covariates

HIV/HCV coinfected

$(n=3,558)$
Not HIV/HCV coinfected

$(n=58,072)$

aHR $[95 \%$ CI $]$ p-value aPAF (\%) [95\% CI] aHR [95\% CI] p-value aPAF (\%) $[95 \%$ CI $]$

\begin{tabular}{|c|c|c|c|c|c|c|}
\hline Central-West (ref) & \multicolumn{2}{|l|}{1} & \multicolumn{4}{|c|}{1} \\
\hline Southeast & $0.68[0.56-0.82]$ & $<10^{-3}$ & & $1.02[0.99-1.06]$ & 0.225 & \\
\hline North & $1.37[0.97-1.92]$ & 0.072 & NA & $1.28[1.22-1.34]$ & $<10^{-3}$ & NA \\
\hline Northeast & $0.79[0.60-1.03]$ & 0.086 & & $1.14[1.10-1.19]$ & $<10^{-3}$ & \\
\hline South & $0.74[0.62-0.90]$ & 0.002 & & $1.08[1.03-1.12]$ & $<10^{-3}$ & \\
\hline \multicolumn{7}{|l|}{ HBV coinfection ${ }^{\S \S}$} \\
\hline Not HBV coinfected (ref) & \multicolumn{2}{|l|}{1} & \multicolumn{4}{|c|}{1} \\
\hline HBV coinfected & $1.55[1.36-1.76]$ & $<10^{-3}$ & $2.62[1.78-3.45]$ & $1.20[1.13-1.27]$ & $<10^{-3}$ & $0.29[0.19-0.40]$ \\
\hline \multicolumn{7}{|l|}{ ART status according to CD4 } \\
\hline \multicolumn{7}{|l|}{ count $\left(\right.$ cells $\left./ \mathrm{mm}^{3}\right)$ at $\mathrm{ART}$} \\
\hline initiation $^{\S \S \S}$ & & & & & & \\
\hline
\end{tabular}




\section{Covariates}

HIV/HCV coinfected

$(n=3,558)$
Not HIV/HCV coinfected

$(\mathrm{n}=58,072)$

aHR [95\% CI] p-value aPAF (\%) [95\% CI] aHR [95\% CI] p-value aPAF (\%) $[95 \%$ CI]

\begin{tabular}{lcccccc}
\hline ART-treated / CD4 $\geq 200$ (ref) & 1 & & & 1 & \\
ART-untreated & $1.43[1.30-1.58]$ & $<10^{-3}$ & $7.12[5.20-9.01]$ & $1.81[1.77-1.85]$ & $<10^{-3}$ & $14.55[14.00-15.09]$ \\
& & & & & & \\
ART-treated / CD4 <200 & $1.85[1.66-2.05]$ & $<10^{-3}$ & $7.92[6.51-9.31]$ & $2.58[2.51-2.64]$ & $<10^{-3}$ & $14.60[14.20-15.00]$ \\
ART-treated / unrecorded CD4 & $1.12[1.03-1.22]$ & 0.009 & $3.52[0.87-6.10]$ & $1.34[1.31-1.38]$ & $<10^{-3}$ & $5.80[5.31-6.28]$
\end{tabular}

aHR, adjusted hazard ratio; aPAF, adjusted population attributable fraction; ART, antiretroviral therapy; CI, confidence interval; HBV, hepatitis B virus; $\mathrm{HCV}$, hepatitis $\mathrm{C}$ virus; IDU, injecting drug use; MSM, men who have sex with men; NA, not applicable.

$\S$ Fixed covariate, measured at baseline.

$\$ \S$ Fixed covariate, measured at baseline or at death (i.e., death notification).

$\S \S \S$ Time-varying covariate. 
Table 4. Factors associated with all-cause mortality in the study population by region of residence (multivariable analyses, extended Cox model with multiple imputation, Brazil, 2007-2015, N=411,028)

\begin{tabular}{|c|c|c|c|c|c|}
\hline \multirow{4}{*}{ Covariates } & \multicolumn{5}{|c|}{ All-cause deaths $(n=61,630)$} \\
\hline & Central-West & Southeast & North & Northeast & South \\
\hline & $(n=3,654)$ & $(n=30,352)$ & $(n=4,301)$ & $(\mathrm{n}=9,293)$ & $(n=14,030)$ \\
\hline & aHR $[95 \% \mathrm{CI}]$ & aHR $[95 \% \mathrm{CI}]$ & aHR $[95 \% \mathrm{CI}]$ & $\operatorname{aHR}[95 \% \mathrm{CI}]$ & aHR $[95 \% \mathrm{CI}]$ \\
\hline \multicolumn{6}{|l|}{ Age (years) ${ }^{\S}$} \\
\hline $18-39$ (ref) & 1 & 1 & 1 & 1 & 1 \\
\hline $40-49$ & $1.33[1.23-1.44]$ & $1.21[1.18-1.24]$ & $1.18[1.10-1.27]$ & 1.13 [1.08-1.19] & $1.29[1.24-1.34]$ \\
\hline$\geq 50$ & $1.87[1.71-2.05]$ & $1.72[1.67-1.77]$ & $1.65[1.51-1.80]$ & $1.53[1.44-1.62]$ & 1.84 [1.76-1.93] \\
\hline \multicolumn{6}{|l|}{ Gender $^{\S}$} \\
\hline Female (ref) & 1 & 1 & 1 & 1 & 1 \\
\hline Male & $1.49[1.38-1.61]$ & $1.47[1.43-1.51]$ & $1.45[1.35-1.56]$ & $1.55[1.47-1.62]$ & $1.65[1.59-1.72]$ \\
\hline Ethnicity ${ }^{\S}$ & & & & & \\
\hline
\end{tabular}




\begin{tabular}{|c|c|c|c|c|c|}
\hline \multirow{4}{*}{ Covariates } & \multicolumn{5}{|c|}{ All-cause deaths $(n=61,630)$} \\
\hline & Central-West & Southeast & North & Northeast & South \\
\hline & $(n=3,654)$ & $(n=30,352)$ & $(n=4,301)$ & $(\mathrm{n}=9,293)$ & $(n=14,030)$ \\
\hline & aHR $[95 \% \mathrm{CI}]$ & aHR $[95 \% \mathrm{CI}]$ & aHR $[95 \% \mathrm{CI}]$ & $\operatorname{aHR}[95 \% \mathrm{CI}]$ & aHR $[95 \% \mathrm{CI}]$ \\
\hline Caucasian (ref) & 1 & 1 & 1 & 1 & 1 \\
\hline Non-Caucasian & 1.15 [1.06-1.25] & $1.12[1.09-1.16]$ & $1.14[1.04-1.26]$ & $1.11[1.04-1.18]$ & 1.27 [1.22-1.33] \\
\hline \multicolumn{6}{|l|}{ Education level ${ }^{\S}$} \\
\hline Higher education (ref) & 1 & 1 & 1 & 1 & 1 \\
\hline Basic education & $1.24[1.06-1.44]$ & $1.25[1.19-1.30]$ & 1.25 [1.12-1.39] & $1.18[1.07-1.30]$ & 1.39 [1.30-1.48] \\
\hline Illiteracy & $1.45[1.13-1.86]$ & $1.65[1.52-1.80]$ & 1.58 [1.31-1.89] & $1.44[1.26-1.64]$ & $2.26[2.02-2.53]$ \\
\hline \multicolumn{6}{|l|}{ HIV transmission mode ${ }^{\S}$} \\
\hline MSM/bisexual (ref) & 1 & 1 & 1 & 1 & 1 \\
\hline Heterosexual & $1.33[1.20-1.46]$ & $1.27[1.23-1.32]$ & $1.16[1.05-1.27]$ & $1.27[1.20-1.35]$ & 1.23 [1.16-1.30] \\
\hline IDU & $1.95[1.41-2.70]$ & 1.65 [1.53-1.79] & $1.52[0.95-2.42]$ & $1.96[1.56-2.47]$ & $1.84[1.65-2.04]$ \\
\hline
\end{tabular}




\begin{tabular}{|c|c|c|c|c|c|}
\hline \multirow{4}{*}{ Covariates } & \multicolumn{5}{|c|}{ All-cause deaths $(n=61,630)$} \\
\hline & \multirow{2}{*}{$\begin{array}{l}\text { Central-West } \\
\qquad(n=\mathbf{3 , 6 5 4})\end{array}$} & \multirow{2}{*}{$\begin{array}{l}\text { Southeast } \\
(n=30,352)\end{array}$} & \multirow{2}{*}{$\begin{array}{c}\text { North } \\
(n=4,301)\end{array}$} & \multirow{2}{*}{$\begin{array}{l}\text { Northeast } \\
(n=9,293)\end{array}$} & \multirow{2}{*}{$\begin{array}{c}\text { South } \\
(n=14,030)\end{array}$} \\
\hline & & & & & \\
\hline & $\operatorname{aHR}[95 \% \mathrm{CI}]$ & aHR $[95 \% \mathrm{CI}]$ & aHR $[95 \% \mathrm{CI}]$ & $\operatorname{aHR}[95 \% \mathrm{CI}]$ & $\operatorname{aHR}[95 \% \mathrm{CI}]$ \\
\hline \multicolumn{6}{|l|}{ HCV coinfection ${ }^{\S \S}$} \\
\hline Not HCV coinfected (ref) & 1 & 1 & 1 & 1 & 1 \\
\hline $\mathrm{HCV}$ coinfected & $2.39[1.99-2.85]$ & $1.71[1.63-1.79]$ & $2.53[1.90-3.37]$ & $1.74[1.43-2.11]$ & $1.68[1.57-1.78]$ \\
\hline \multicolumn{6}{|l|}{ HBV coinfection ${ }^{\S \S}$} \\
\hline Not HBV coinfected (ref) & 1 & 1 & 1 & 1 & 1 \\
\hline HBV coinfected & $1.36[1.10-1.67]$ & $1.26[1.17-1.35]$ & 1.59 [1.27-1.99] & $1.22[1.00-1.49]$ & $1.14[1.02-1.28]$ \\
\hline \multicolumn{6}{|c|}{ ART status according to CD4 count } \\
\hline$\left(\right.$ cells $\left./ \mathbf{m m}^{3}\right)$ at $\mathrm{ART}$ initiation ${ }^{\S \S \S}$ & & & & & \\
\hline
\end{tabular}




\begin{tabular}{|c|c|c|c|c|c|}
\hline \multirow{4}{*}{ Covariates } & \multicolumn{5}{|c|}{ All-cause deaths $(n=61,630)$} \\
\hline & Central-West & Southeast & North & Northeast & South \\
\hline & $(n=3,654)$ & $(n=30,352)$ & $(n=4,301)$ & $(n=9,293)$ & $(n=14,030)$ \\
\hline & aHR $[95 \% \mathrm{CI}]$ & aHR $[95 \% \mathrm{CI}]$ & aHR $[95 \% \mathrm{CI}]$ & $\operatorname{aHR}[95 \% \mathrm{CI}]$ & aHR $[95 \% \mathrm{CI}]$ \\
\hline ART-treated / CD4 $\geq 200$ (ref) & 1 & 1 & 1 & 1 & 1 \\
\hline ART-untreated & $1.95[1.77-2.15]$ & $1.68[1.63-1.73]$ & $2.58[2.36-2.81]$ & $2.11[1.99-2.23]$ & $1.59[1.51-1.67]$ \\
\hline ART-treated / CD $4<200$ & $2.37[2.14-2.63]$ & $2.56[2.47-2.65]$ & $3.50[3.19-3.83]$ & $2.39[2.25-2.55]$ & $2.43[2.31-2.56]$ \\
\hline ART-treated / unrecorded CD4 & $1.23[1.12-1.36]$ & $1.33[1.29-1.37]$ & $2.04[1.79-2.32]$ & $1.30[1.21-1.40]$ & $1.25[1.19-1.31]$ \\
\hline
\end{tabular}

aHR, adjusted hazard ratio; aPAF, ART, antiretroviral therapy; CI, confidence interval; HBV, hepatitis B virus; HCV, hepatitis C virus; IDU, injecting drug use; MSM, men who have sex with men.

${ }^{\S}$ Fixed covariate, measured at baseline.

$\S \S$ Fixed covariate, measured at baseline or at death (i.e., death notification).

$\$ \$$ Time-varying covariate. 